\title{
Study of arsenic distribution in sediments of the southeastern Caspian sea
}

\author{
Hossein Bagheri $^{{ }^{*}}$; Mohammad Hossein Mahmodi Gharaei ${ }^{1}$, Seyed Reza Mossavi Harami ${ }^{1}$, Zahra Bagheri ${ }^{2}$ \\ ${ }^{1}$ Department of Geology, Faculty of Sciences, Ferdowsi University of Mashhad International Campus, Iran \\ ${ }^{2}$ Tarbiat Modares University, Department of Environmental Science, Iran \\ *Corresponding author E-mail: Bagheryl @ gmail.com
}

Copyright $(\mathcal{O} 2015$ Hossein Bagheri et al. This is an open access article distributed under the Creative Commons Attribution License, which permits unrestricted use, distribution, and reproduction in any medium, provided the original work is properly cited.

\begin{abstract}
Geochemical studies of sediments, water bodies like rivers, estuaries and the sea bed, can be an effective step to find the source and distribution model assessment of environmental pollutants in a region. Sediments are the final destination of heavy metals in aqueous environments contamination, including arsenic entering the water resources in different ways, causing hazards such as poisoning, and carcinogenesis in living bodies. Study arsenic levels in the eastern part of the Caspian Sea, 30 stations were selected in the Calculation of aggregated fine-grained organic matter in two seasons of the arsenic concentration in both summer and winter by using Inductively Coupled Plasma - Mass spectrometry (ICPMS) was determined. Geochemical index, Enrichment factor and pollution index were determined low pollution to nonpollution area and cause of arsenic to the environment, erosion of the Geological formation of the bay, leading GORGAN River carry deposits upstream of surroundings were. Primary cause of arsenic to the environment, geology and upstream sediment erosion and transport by rivers is leading to Gorgan Bay and surrounding areas. Compare these results with other parts of the Caspian Sea show that arsenic levels observed in this study in the Gorgan Bay and surrounding areas has been less than other part of the Caspian Sea.
\end{abstract}

\section{Introduction}

Heavy metal elements in coastal sediment originate from physical and chemical weathering of parent rocks, wastewater discharge and atmospheric deposition [10]. Heavy metals discharged into aquatic system during their transport are distributed between the aqueous phase and sediments. Because of adsorption, Hydrolysis and co-precipitation of metal ions, a large quantity of them are deposited in the sediment while only a small portion of free metal ions stay dissolved in water column. The accumulation and mobility of heavy metals in sediments controlled by various factors such as nature of the sediment particles, properties of adsorbed compounds, metal characteristics, redox reactions and biodegradation of sportive substance under specific conditions [1-7-8-9-13-17-22-39-47-49-52-53-54]. Among these elements, arsenic is highly toxic to the natural environment is one of the most important. Behavior of arsenic as a toxic substance and chemical pollutants is well known that the presence of water is undesirable effects on the health of living organisms.Arsenic can be found naturally on earth in small concentrations. It occurs in soil and minerals and it may enter air, water and land through wind-blown dust and water run-off. Arsenic in the atmosphere comes from various sources: vulcanoes release about 3000 tonnes per year and microorganisms release volatile methyl arsines to the extent of 20.000 tonnes per year, but human activity is responsible for much more: 80.000 tonnes of arsenic per year are released by the burning of fossil fuels. Despite the numerous studies on metal sediment contamination of the bay, estuary and harbor that have been conducted in developed countries, heavy metal evaluation has not been yet done systematically for sediments in the Gorgan Bay, Iran. Regarding to the crucial importance of such a unique ecosystem, the researchers of this paper aimed: 1) to investigate the spatial distribution of Arsenic in surface sediments of Gorgan Bay; 2) to evaluate the anthropogenic activities impact on Arsenic contamination using Geoaccumulation Index and 
Enrichment Factor 3) to assess the pollution level in Gorgan Bay using the Degree of Contamination Index 4) to represent the relationship between chemical contamination in the sediment and its toxic biological effects on aquatic organisms under the sediment quality instructions of NOAA which is widely adopted.

\section{Study area}

Gorgan Bay, strategically located at the southeastern of the Caspian Sea with $60 \mathrm{~km}$ length and $12 \mathrm{~km}$ width, is a semienclosed basin, as it receives no wave's energy from the Caspian Sea (fig.1). The Bay is mostly affected by the currents originating from inside the basin. This area is best known for its high economic and ecological importance as a fishing and recreational ground because of appropriate biological conditions for aquatic animals. Gorgan Bay is the ultimate sink for water flows from Gharehso River. Gorgan River faces the Caspian Sea at the vicinity of the Bay mouth at northeast part [13].

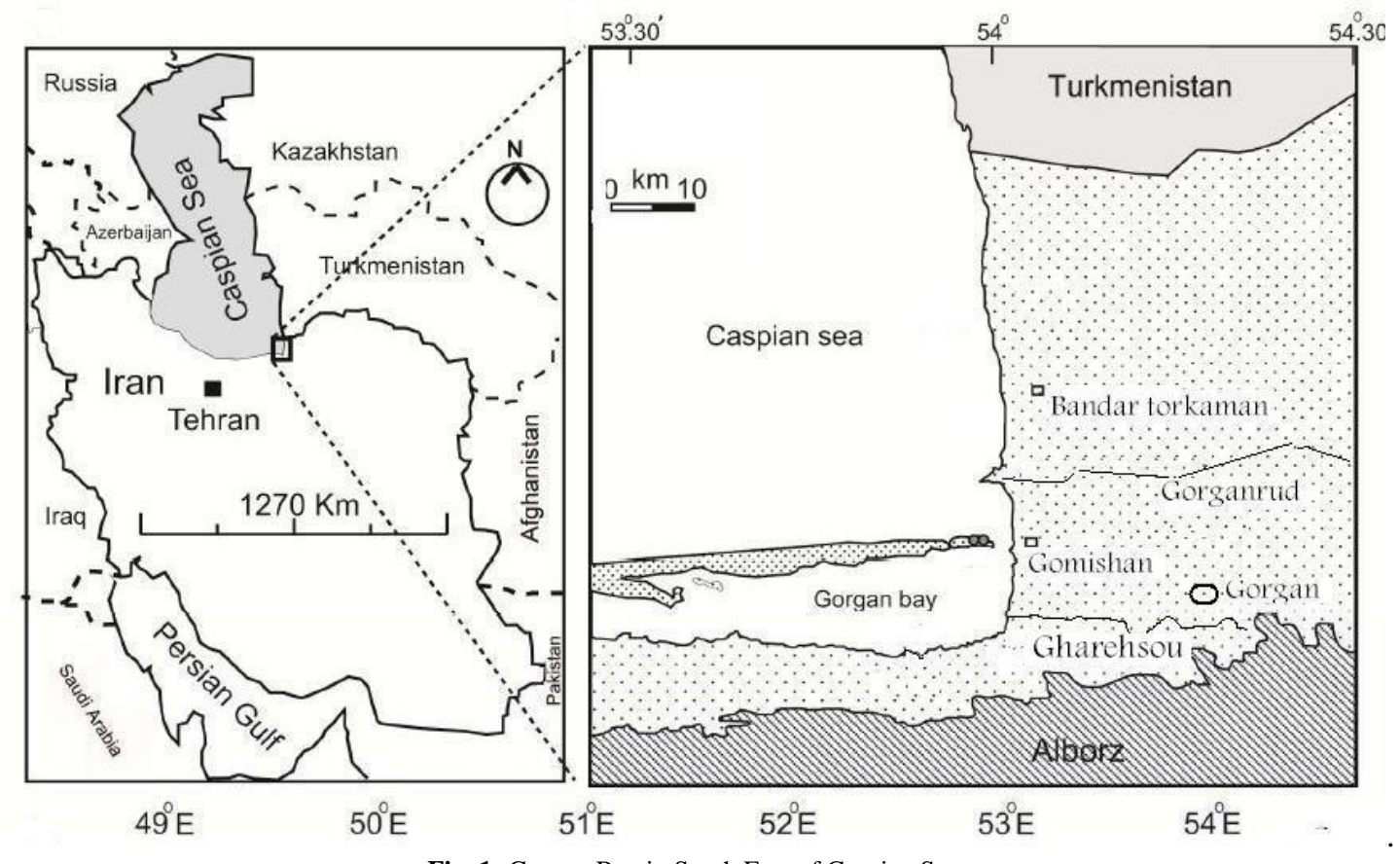

Fig. 1: Gorgan Bay in South East of Caspian Sea

\section{Material and method}

\subsection{Sediment sampling and analysis}

After revision of the Gorgan Bay map and field patrolling, 30 sites were selected and surface sediment sampling ( 5 $\mathrm{cm}$ ) was carried out using Van-Veen type grab in 2 dry and wet season,(July and November 2012).The geographical locations of the sampling sites were recorded using a hand held GPS (eTrax, Garmin) for geo-statistical analysis (Fig.2). After sampling, sediment samples were packed and carried to the laboratory in iced-boxes and stored at $4{ }^{\circ} \mathrm{C}$ until analysis. Sediment samples were divided into two portions, one for measuring grain size, organic matter and calcium carbonate content, and the other for heavy metal analysis, respectively. After the sediment samples were dried in an oven and stone pieces were removed, they were ground by using a hand mortar. For digestion of sediment samples, $0.5 \mathrm{~g}$ of each sediment sample were added with a mixture of $\mathrm{HCl}-\mathrm{HNO} 3-\mathrm{H} 2 \mathrm{O}$ (with the ratio of 1:1:1 v/v) and heated at 95 ${ }^{\circ} \mathrm{C}$ during $1 \mathrm{hr}$. In the laboratory, the samples were analyzed $(\mathrm{Pb}, \mathrm{Cu}, \mathrm{Zn}$ and $\mathrm{Cr}$ ) by using inductively coupled plasma mass spectroscopy (ICP-MS; Perkin-Elmer ELAN9000) at ACME Analytical Laboratories Ltd. in Canada (http://www.acmelab.com/cfm/index.cfm). ACME is currently registered with ISO 9001:2000 accreditation. Standard samples (Oreas 45Pa, DS7 and DS8) were used to monitor the performance of the instrument and the data quality. The analytical results of the quality control samples show good agreement with the certified values (recoveries ranging 94.04-107.89\%). The minimum detection limits were: $0.1 \mathrm{ppm}$.

To assess total organic matter, sediment samples were dried at $70^{\circ} \mathrm{C}$ for $24 \mathrm{hrs}$ and then combusted in an oven at $550^{\circ} \mathrm{C}$ for $4 \mathrm{hrs}$. Total organic matter, as described by [1], was measured by the following equation:

Total organic matter $(\mathrm{TOM}, \%)=(\mathrm{B}-\mathrm{C} / \mathrm{B}) \times 100$

Where $\mathrm{B}$ and $\mathrm{C}$ : are the weights of dried sediment before and after combusting in the oven, respectively. 
Sediment grain size analysis was made from soil samples collected in separate polythene bags. For that, samples were air dried and sieved through a mechanical sieve to remove shells, debris, etc. Dried sediment samples were subjected to size fraction analysis following the procedure of Wentworth (1992). $100 \mathrm{~g}$ of sample was taken and sieved through a 62 $\mu \mathrm{m}$ mesh-sized screen for $10 \mathrm{~min}$ in a mechanical sieve shaker. The sample that remained in the sieve was weighed and treated as sand. The sediment samples which passed through the sieve were the silt and clay. The silt and clay fractions were then separated by means of pipette method, described by Lindholm (1987) [35]. Method of volumetric and Barnard calcimetry was applied to determine calcium carbonate content [34].

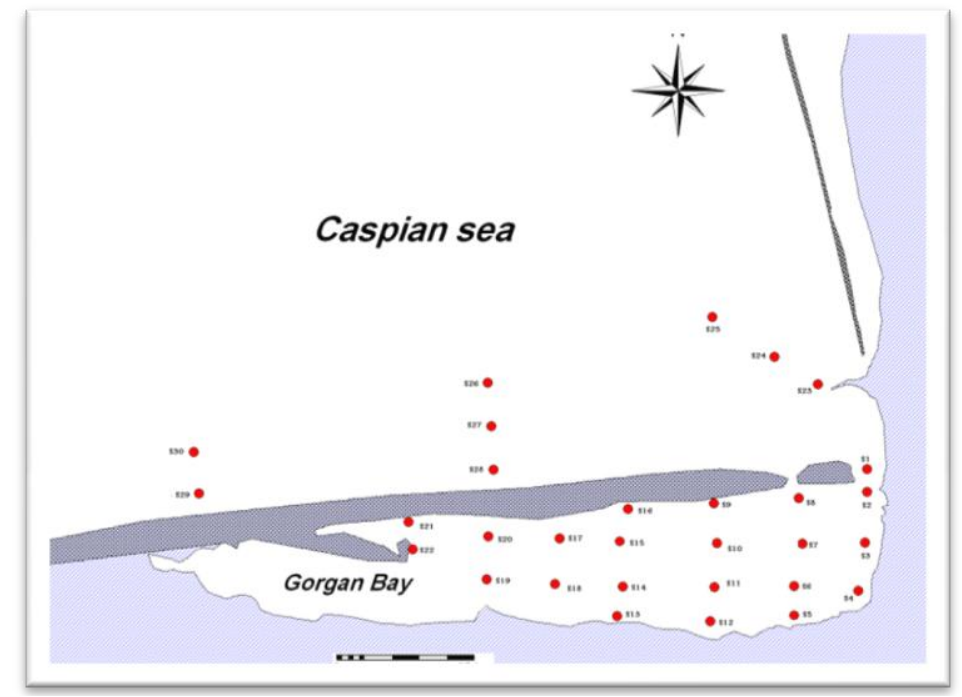

Fig. 2: Sampling Location in 2 Seasons

\subsection{Assessment of heavy metals pollution}

To estimate the present heavy metal (especially as) pollution and compare to previous condition, Muller Index (geochemical index) was applied [43]. as the fallowing equation:

$\operatorname{Igeo}=\log 2(\mathrm{Cn} / 1.5 \mathrm{Bn})$

Where $\mathrm{Cn}$ and $\mathrm{Bn}$ : are heavy metal content in the sampled sediment and intact sediment before industrilization, respectively. Because of geolocial and litological impacts, the correction coefficient of the initial sediment concentration (1.5) was applied.

Seven calsses were proposed by Muller Index in which values of metals are at least 100 times more than refrence value in the upper class order [64].

The Igeo is associated with a qualitative scale of pollution intensity, samples may be classified as: unpolluted (Igeo $\leq 0$ ), unpolluted to moderately polluted $(0 \leq$ Igeo $\leq 1)$, moderately polluted $(1 \leq$ Igeo $\leq 2)$, moderate to strongly polluted ( $2 \leq$ Igeo $\leq 3)$, strongly polluted $(3 \leq$ Igeo $\leq 4)$, strongly to extremely polluted $(4 \leq$ Igeo $\leq 5)$, and extremely polluted (Igeo $\geq 5$ ). a sediment sample were selected from depth of $1 \mathrm{~m}$ of substrate and used as the back ground concentrations of the metals in Goegan Bay (As 5, Pb 6, Cu 10, Zn 31, Cr 17 ppm and Al 1.09 \%, [4].

Enrichment Factor (EF), an appropriate instrument to determine sedimentary metals source produced by anthropogenic events or natural origin [2-28-29-33-37-42-48-51]. Normalizes metals concentrations according to the sediment texture properties. In this index, Aluminum is widely used, indicating aluminum silicate at coastal areas where this element is predominant. Enrichment Factor is also applied as a degree of sedimentation [26-31-60]. And determined as follows:

Enrichment Factor $=$ (Hs / Als) / (Hc / Alc)

Where Hs and Hc: are heavy metal concentrations in sample and background reference, respectively. Als and Alc: are the aluminum contents in sample and background reference, respectively.

Contamination Factor for each sedimentary metal and Degree of Contamination, as suggested by Hakanson (1980) were used to estimate the pollution level as the following equation:

Contamination factor: $\mathrm{Hs} / \mathrm{Hb}$

Where $\mathrm{Hs}$ and $\mathrm{Hb}$ : are the heavy metal contents in sample and background reference, respectively.

Degree of Contamination Index was calculated by total sum of the contamination factor for each sedimentary metal. The classification of the sediments according to the contamination factor is as following:

$\mathrm{Cf}<1=$ low contamination factor

$1 \leq \mathrm{Cf}<3=$ moderate contamination factor

$3 \leq \mathrm{Cf}<6=$ considerable contamination factor

$\mathrm{Cf} \geq 6=$ very high contamination factor

The following terminology has been used for the degree of contamination of each site in the present study: 


\section{Sediment quality guidelines}

To predict detrimental biological effects and conservation of the organisms living inside or near the polluted sediments, the method of Sediment Quality Guidelines was applied.

\section{Geochemical mapping}

Geospatial method is the most effective approach to comprehend the polluted sites as well as to take an image of these points in a vast area. Sedimentary metal concentrations and geographical location of the sampling sites were used as input data into Iiwise (Ver. 3) to extract geographical mapping of sedimentary metal dispersion in surface sediments of the Bay.

\section{Results and discussion}

Highest and lowest rates of organic matter in the winter (wet season) in Gorgan Bay, respectively, 8.94 and $2.38 \%$ and average $6.36 \pm 2.32 \%$ (the lowest and highest at Station 16 Station 21 respectively). Mud and Sand is also highest in this chapter in the order in Gorgan Bay stations 9 and 16, respectively (Table 1). While the highest and lowest levels of organic matter in the summer (dry season) were 9.92 and $2.95 \%$ respectively (the lowest in 16 and highest in station 21 with the mean: $6.25 \pm 1.56$ ) and for Mud and Sand the highest and lowest at stations 5 and 16, were obtained respectively. in Caspian Sea is the largest and lowest organic matter, respectively, 6.34 and 2.42 percent for the wet season (Station 29 and Station 26) 6.59 and 2.2 for the dry season (minimum in 28 and maximum in 23) and the highest Mud and Sand at stations 23 and 28, respectively (table 1).

The maximum amount of arsenic in Gorgan Bay in winter at the station $16(6.30 \mathrm{~g} / \mathrm{kg})$ and the lowest at station $22(.96$ $\mathrm{g} / \mathrm{kg}$ ) was observed, and the maximum amount of summer at stations 12 and $16(14.33 \mathrm{~g} / \mathrm{kg})$ and lowest in station 8 and $11(3.33 \mathrm{~g} / \mathrm{kg})$ was observed while the highest value of arsenic in two seasons in the Caspian Sea stations 27 and 29 and the lowest was observed at station 23 (table 1). Results of Geoaccumulation Index are shown in Tables1 demonstrate that Gorgan Bay is classified as unpolluted to moderately polluted Bay. Negative and zero values shows that sediments undisturbed and arsenic concentrated in the last sediments due to the humid climate of the region and upstream erosion.

EF is widely used as an indicator to assess the status of environmental contamination. Yet, threshold values of the element enrichment have not been recognized. For example, Blaser et al. (2000) [6] reported that an EF > 1 indicated the occurrence of metal element enrichment in soils. However, as defined by Liaghati et al. (2004) EF > 2 reflects enrichment. Sutherland (2000) developed the following five categories: $\mathrm{EF}<2$, deficiency to minimal enrichment; $\mathrm{EF}=$ 2-5, moderate enrichment; $\mathrm{EF}=5-20$, significant enrichment; $\mathrm{EF}=20-40$, very high enrichment; and $\mathrm{EF}>40$, extremely high enrichment. Many researchers have applied this index in contamination assessments of heavy metals [11-12-18-1920-21-23-46].

The range of this factor for As was from .38 to 2.8 at all sites for wet season and 1-4.62for dry season respectively, which represent the low Enrichment to moderate enrichment in Gorgan Bay. Most of the heavy metals in the southern part of the Caspian Sea basin are the result of erosion of rocks while in the northern parts is main industries [4].The major factors affecting spatial variation of heavy metals in the sediment are TOM and the grain size [3-25]. The fine grains, representing the higher rate of surface to volume and ionic absorption power, are more capable in the absorption of contaminated organic and inorganic materials [40-24]. Generally, fine-grained sediments carrying lots of organic matter are more contaminated than coarse-grained sediments [14-15]. But in this study, there was significantly a positive relationship between the sand and sedimentary as content while a negative correlation was found between TOM and mud with Arsenic $(\mathrm{p}<0.01)$ (Table 2) and may be related to geology. The geology plays a crucial role in arsenic mitigation [27]. Sediments typically contain only modest levels of arsenic and the cause and timing of arsenic mobilization from these sediments remain unclear. Vulnerable areas for arsenic contamination are typically young Quaternary deltaic and alluvial sediments [5], with a typically high content of organic matter [27]. Moreover, Berg et al. (2007) found a correlation with sediment-bound iron. Studies in Bangladesh, which is largely located on large delta plain, clearly show that geology needs to be considered. The sediments originate from the Alborz mountain range and have been deposited over millions of years. Deep and old sediments built during the Pleistocene - contain arsenic tightly bound to iron (hydroxides), leading to low arsenic concentrations. During the Holocene, due to the rising sea levels, younger sediments consisting of sands, silts, and clays have filled the valleys and lower terraces and transported with river to the area (fig. 3,4$)$. 


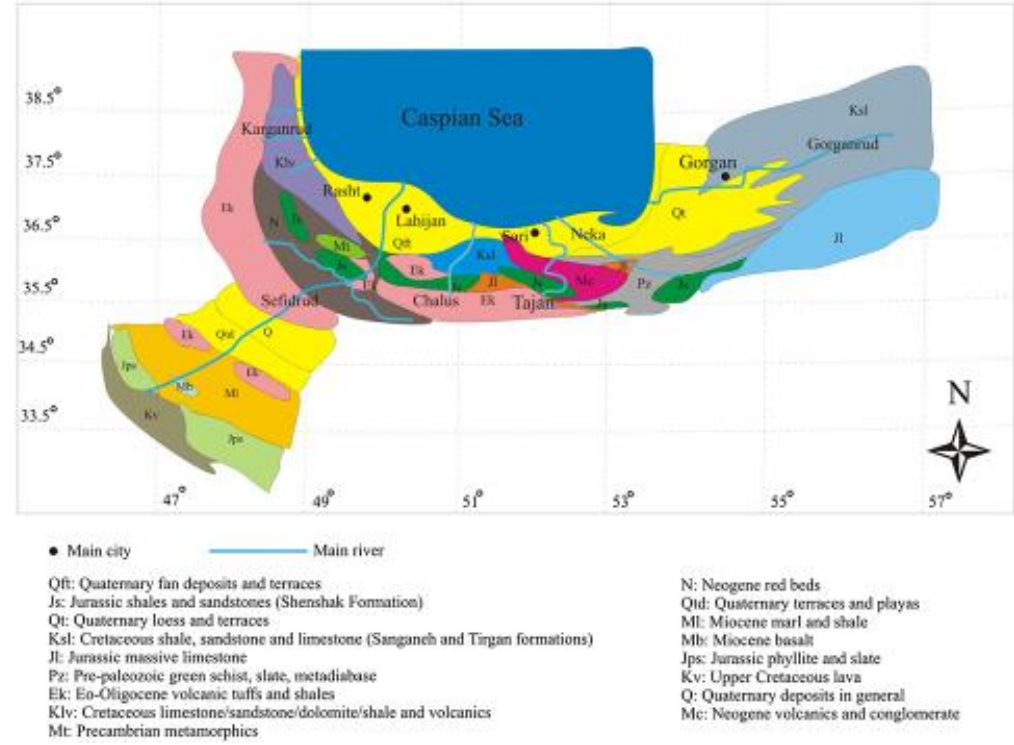

Fig. 3: Geological Map of Study Area (after Lahijani,2011)[4]
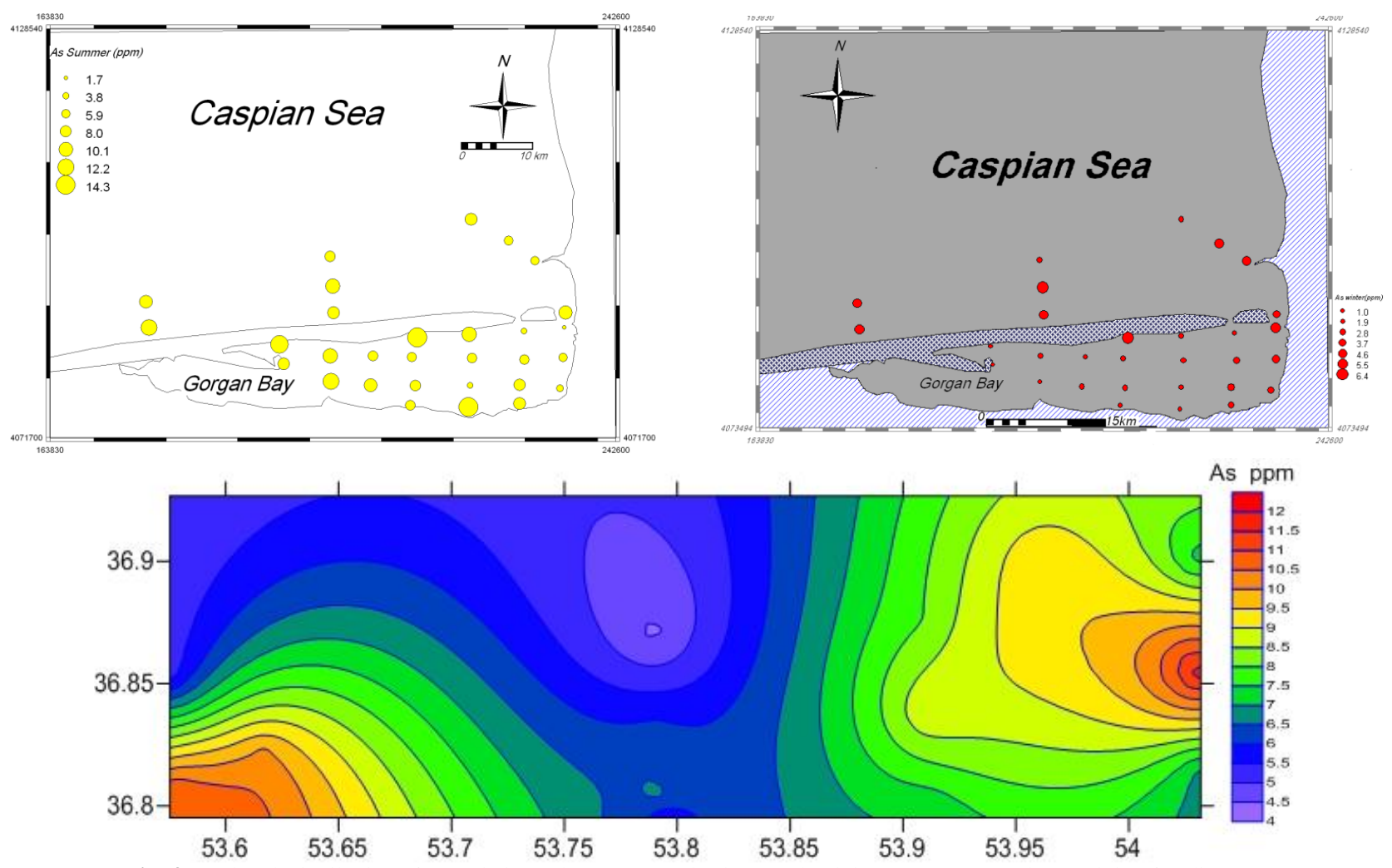

Fig. 4: Regional Distribution of Arsenic in Both Summer and Winter and Origin (Contour Map Show Origin of Sediments)

\section{Contamination factor and degree of contamination}

The highest and the lowest contamination factors for tow season (wet \&dry) were obtained (1.27-0.19 \&2.87-0.67). This factor show low contamination $(<1)$ in wet season and moderate contamination factor in dry season $1 \leq \mathrm{Cf}<3$ ). This higher contamination load might be implicated to arsenic containing inputs of Ghareso and Gorganrud River where discharges to Gorgan Bay along the east shoreline, in particular adjacent to sites 3 and 4, reflecting the river exposure to the industrial effluents and urban wastewaters. Considering higher contamination of heavy metals in sediments sampled from north and northeast parts of the Bay than those sampled from the central and west parts, this might be perceived that metals accumulation in sediments of the former parts are influenced by water flows from Ghareso River as a considerable source of metals pollution. 
Table 1: Table of Different Analysis and Parameters an Dry and Wet Season

\begin{tabular}{|c|c|c|c|c|c|c|c|c|c|c|c|c|c|c|}
\hline \multirow[b]{2}{*}{$\mathrm{St}$} & \multirow[b]{2}{*}{ Sand $\%$} & \multicolumn{7}{|c|}{ Wet } & \multicolumn{6}{|c|}{ Drv } \\
\hline & & Mud & TOM & As & Igeo & $\mathrm{Cf}$ & Ef & Sand & Mud & TOM & As & Igeo & $\mathrm{Cf}$ & $\mathrm{Ef}$ \\
\hline 1 & 38.79 & 61.21 & 7.62 & 3.76 & -1.00 & 0.75 & 1.65 & 38.4 & 61.26 & 5 & 9.66 & 0.37 & 1.93 & 3.12 \\
\hline 2 & 39.31 & 60.69 & 4.16 & 5.20 & -0.53 & 1.04 & 2.71 & 44.71 & 55.29 & 3.78 & 11.66 & 0.64 & 2.33 & 3.76 \\
\hline 3 & 38.91 & 61.09 & 7.03 & 3.83 & -0.97 & 0.77 & 1.99 & 52.92 & 47.08 & 4.35 & 5.33 & -0.49 & 1.07 & 1.72 \\
\hline 4 & 33.66 & 66.34 & 4.52 & 3.03 & -1.31 & 0.61 & 1.30 & 59.3 & 40.7 & 5.36 & 4.33 & -0.79 & 0.87 & 1.40 \\
\hline 5 & 30.24 & 69.76 & 7.64 & 2.56 & -1.55 & 0.51 & 2.48 & 4.32 & 96.68 & 5.98 & 8.66 & 0.21 & 1.73 & 2.79 \\
\hline 6 & 41.49 & 58.51 & 7.72 & 3.30 & -1.18 & 0.66 & 2.54 & 35.82 & 64.18 & 7.06 & 8.00 & 0.09 & 1.60 & 2.58 \\
\hline 7 & 21.53 & 78.47 & 8.14 & 2.80 & -1.42 & 0.56 & 1.28 & 31.56 & 68.44 & 5.9 & 6.33 & -0.24 & 1.27 & 2.04 \\
\hline 8 & 46.22 & 53.78 & 7.91 & 1.90 & -1.98 & 0.38 & 0.61 & 49.76 & 50.24 & 6.35 & 3.33 & -1.17 & 0.67 & 1.07 \\
\hline 9 & 4.7 & 95.3 & 6.85 & 2.36 & -1.67 & 0.47 & 0.76 & 57.87 & 42.13 & 5.61 & 10.66 & 0.51 & 2.13 & 3.44 \\
\hline 10 & 55.82 & 44.18 & 8.58 & 2.23 & -1.75 & 0.45 & 0.54 & 44.72 & 55.28 & 7.74 & 6.33 & -0.24 & 1.27 & 1.53 \\
\hline 11 & 44.4 & 55.6 & 6.71 & 1.86 & -2.01 & 0.37 & 0.60 & 57.52 & 42.48 & 5.76 & 3.33 & -1.17 & 0.67 & 1.07 \\
\hline 12 & 12.76 & 87.24 & 7.72 & 1.53 & -2.29 & 0.31 & 0.49 & 61.26 & 38.74 & 5.4 & 14.33 & 0.93 & 2.87 & 4.62 \\
\hline 13 & 40.84 & 59.16 & 4.75 & 1.53 & -2.29 & 0.31 & 0.49 & 11.72 & 89.25 & 7.72 & 7.00 & -0.10 & 1.40 & 2.26 \\
\hline 14 & 38.54 & 61.46 & 7.1 & 2.26 & -1.73 & 0.45 & 0.73 & 54.92 & 45.08 & 6.1 & 7.33 & -0.03 & 1.47 & 2.37 \\
\hline 15 & 59.27 & 40.73 & 8.55 & 2.13 & -1.82 & 0.43 & 0.69 & 65.56 & 34.44 & 6.25 & 6.00 & -0.32 & 1.20 & 1.94 \\
\hline 16 & 87.73 & 12.27 & 2.38 & 6.30 & -0.25 & 1.26 & 2.03 & 75.38 & 24.62 & 2.95 & 14.33 & 0.93 & 2.87 & 4.62 \\
\hline 17 & 40.84 & 59.16 & 7.01 & 2.16 & -1.80 & 0.43 & 0.70 & 62.21 & 37.79 & 6.53 & 6.66 & -0.17 & 1.33 & 2.15 \\
\hline 18 & 52.41 & 47.59 & 7.5 & 2.36 & -1.67 & 0.47 & 0.76 & 65.18 & 34.82 & 6.7 & 9.33 & 0.31 & 1.87 & 3.01 \\
\hline 19 & 32.46 & 67.54 & 8.39 & 1.20 & -2.64 & 0.24 & 0.39 & 80.2 & 11.29 & 6.38 & 12.00 & 0.68 & 2.40 & 3.87 \\
\hline 20 & 48.66 & 51.34 & 8.02 & 2.16 & -1.80 & 0.43 & 0.70 & 68.55 & 31.45 & 8.8 & 11.00 & 0.55 & 2.20 & 3.55 \\
\hline 21 & 27.89 & 72.11 & 8.94 & 1.40 & -2.42 & 0.28 & 0.45 & 51.87 & 48.13 & 9.92 & 13.33 & 0.83 & 2.67 & 4.30 \\
\hline 22 & 33.01 & 66.99 & 8.46 & .96 & -2.97 & 0.19 & 0.31 & 68.44 & 31.56 & 8.03 & 8.33 & 0.15 & 1.67 & 2.69 \\
\hline 23 & 43.17 & 56.83 & 4.40 & 5.32 & -0.50 & 1.06 & 1.72 & 9.25 & 90.75 & 6.52 & 5.33 & -0.49 & 1.07 & 1.72 \\
\hline 24 & 20.86 & 79.14 & 4.80 & 3.78 & -0.99 & 0.76 & 1.22 & 51.31 & 48.69 & 4.35 & 6.00 & -0.32 & 1.20 & 1.94 \\
\hline 25 & 16.4 & 83.6 & 2.36 & 4.34 & -0.79 & 0.87 & 1.40 & 23.18 & 76.82 & 6.59 & 8.66 & 0.21 & 1.73 & 2.79 \\
\hline 26 & 5.29 & 94.71 & 2.60 & 6.34 & -0.24 & 1.27 & 2.05 & 24.76 & 75.24 & 5.66 & 7.33 & -0.03 & 1.47 & 2.37 \\
\hline 27 & - & - & & 6.40 & -0.23 & 1.28 & 2.07 & - & - & - & 10.66 & 0.51 & 2.13 & 3.44 \\
\hline 28 & 66.48 & 33.52 & 4.90 & 2.87 & -1.39 & 0.57 & 0.93 & 88.78 & 11.22 & 2.02 & 8.66 & 0.21 & 1.73 & 2.79 \\
\hline 29 & 85.78 & 14.22 & 5.16 & 2.42 & -1.63 & 0.48 & 0.78 & 85.1 & 13.49 & 2.51 & 11.66 & 0.64 & 2.33 & 3.76 \\
\hline 30 & 41.32 & 58.68 & 4.60 & 3.79 & -0.98 & 0.76 & 1.22 & 44.79 & 55.21 & 5.27 & 9.33 & 0.31 & 1.87 & 3.01 \\
\hline
\end{tabular}

Table 2: Correlation between Mud, Sand, Tom With As

\begin{tabular}{llll}
\hline & Mud & Sand & As \\
\hline Sand & $-0.999 * *$ & & \\
As & $-0.347 * *$ & $0.340 * *$ & -0.211 \\
Tom & 0.209 & $-0.292^{*}$ & \\
\hline
\end{tabular}

\section{Sediment quality guideline}

Sediment is considered as a source of potential contaminated materials. In order to predict harmful biological effects and to conserve the living organisms inhabiting near or inside the sediment, many Sediment Quality Guidelines have been developed since the last decade including: Sediment Quality Criteria, Sediment Quality Standards and Sediment Quality Objects. These guidelines are remedial when evaluating the spatial variation of contamination in the sediment, classifying the sediment contamination condition, planning, supervising and analyzing the historical data as well as assessing future renovation operations for the environment [32-38-45-46-50]. SQGs have been improved by types of approaches viz. Effect range approach, Effect level approach, and Effect threshold approach. It is important to select the most appropriate SQGs. Based on exploitation approach, the aim of calculation and the capability of the guideline corresponding to the geology background of a specific region, the calculated value is markedly different [38].Mostly, SQGs used for marine sediments are established on Sediment Quality Guideline from American NOAA Organization[44]. This guideline is composed of Effect Range Guidelines derived from a series of chemical and biological information collected from coastal areas of Northern America and a combination of experimental and field data obtained by different biological and chemical methods [41]. The effect range of SQGs is attained empirically and is lack of factors like bioavailability of contaminants as well. The concentrations of chemicals which result in $10 \%$ and $50 \%$ of adverse biological effects are called as Effect-range-low (ERL) and Effects-range-medium (ERM), respectively. In order to classify the sediment, NOAA provides two values for each chemical: (1) sediments with rarely adverse biological impacts (<ERL), (2) sediments with occasionally or frequently adverse biological impacts (>ERL and <ERM). Based on Sediment Quality Guideline, results showed that arsenic levels in Gorgan Bay is lower than in other parts of the Sea [13-15] and were lower than determined limits of ERL, ERM, ISQGc and PEL in this study for Wet session and more than ERL, ISQGc for dry session, implicating non-harmful biological impact on living organisms inhabiting in Gorgan Bay (Table 3). But in the summer can be seen that many stations cocentration of As is greater than the quality standardsand further research should be done in this area. The government should rule more severe managing strategies and treating policies on the urban discharges and industrial wastewaters before releasing to the natural environments like rivers and basins. 
Table 3: Comparing Results of This Study with Other Studies and Quality Guidelines

\begin{tabular}{llll}
\hline Region & As (Wet) & As (Dry) & Reference \\
\hline \multirow{2}{*}{ Study area (Iran) } & $3.68 \pm 1.73$ & $8.83 \pm 2.11$ & This study \\
& $.96-6.4$ & $3.33-14.33$ & De Mora et al. (2004) \\
Caspian Sea (Iran) & $12.5 \pm 3.04$ & - & - \\
ERLa & $(6.97-20.1)$ & & - \\
ERMb & 8.2 & - & - \\
ISQGc & 70 & - & - \\
PELd & 7.24 & - & - \\
\hline
\end{tabular}

ERLa: Effect range low (NOAA). ERMb: Effect range medium (NOAA). ISQG c: Interim sediment quality guideline (Environment Canada). PEL d: Probable effects level (Environment Canada).

\section{Conclusion}

The study area is part of the East Alborz Mountains and every years a large amount of terrestrial sediments with many of heavy metals as Arsenic that eroded from upper part of basin import with rivers such as Gorganrud and Gharehsou in this area. Based on the results obtained, the Bay of Gorgan was not severely polluted by Arsenic. Considering Arsenic assessment indices determined here, surface sediments of the Bay could be generally classified as" low to moderatelycontaminated ". The areas with the highest metal inputs were along the east regions toward the northeast part of the Bay. Although sediment samples assessed in the present study imply no relation to adverse biological effects, this semienclosed and sensitive ecosystem is susceptible to various anthropogenic threats which are currently under concern due to their action in disturbing the balance of the ecosystem in near future. Thereafter, the government should rule more severe managing strategies and treating policies on the urban discharges and industrial wastewaters before releasing to the natural environments like rivers and basins. However, we suggest that a longer term ecological study at different seasons should be conducted in order to better predict heavy metal contamination in Gorgan Bay.

\section{Acknowledgement}

We are grateful to Golestan environmental protection office, for their valuable suggestions regarding the present study.

\section{References}

[1] Abrantes A, Pinto F, Moreira M, 1999.Ecology of polychaete Nereis diversicolor, in the Cannal de Mira(Ria de averio,Portugal). Population dynamics, production and oogenic cycle. Acta Oceanology 20(4): 267-283. http://dx.doi.org/10.1016/S1146-609X(99)00139-3.

[2] Adamo P, Arienzo M, Imperato M, Naimo D, Nardi G, Stanzione D, 2005. Distribution and partition of heavy metals in surface and subsurface sediments of Naples city port. Chemosphere 61: 800-809. http://dx.doi.org/10.1016/j.chemosphere.2005.04.001.

[3] Aloupi M, Angelidis MO, 2001. Geochemistry of natural and anthropogenic metals in the coastal sediments of the island of Lesvos, Aegean Sea. Journal of Environmental Pollution, 113: 211-219. http://dx.doi.org/10.1016/S0269-7491(00)00173-1.

[4] Bagheri, H, Darvish Bastami, K, Kheirabadi, V,Ghorbanzadeh Zaferani, V, Teymori, M, Hamzehpoor, A, Soltani,F, Haghparast, S, Moussavi Haram,R Ghorghani,N Ganji, N., 2014. Distribution and ecological risk assessment of heavy metals in surface sediments along southeast coast of the Caspian Sea. Marine Pollution Bulletin 81: 262-267. http://dx.doi.org/10.1016/j.marpolbul.2014.01.029.

[5] Berg M, et al., 2007. Magnitude of arsenic pollution in the Mekong and Red River Deltas-Cambodia and Vietnam. Sci Total Environ 372:413-425Birch GF, Taylor SE, 2006. Application of sediment quality guidelines in the assessment and management of contaminated surficial sediments in Port Jackson (Sydney Harbour), Australia. Journal of Environmental Management, 29: 860-870.

[6] Blaser P, Zimmermann S, Luster J, Shotyk W, 2000. Critical examination of trace element enrichments and depletions in soils: As, $\mathrm{Cr}, \mathrm{Cu}, \mathrm{Ni}$ $\mathrm{Pb}$ and $\mathrm{Zn}$ in Swiss forest soils. Sci. Total Environ. 249: 257-280. http://dx.doi.org/10.1016/S0048-9697(99)00522-7.

[7] Bloom H, Ayling GM, 1977. Heavy metals in the Derwent Estuary. Environmental Geology, 2: 3-22. http://dx.doi.org/10.1007/BF02430661.

[8] Bothner MH, Buchholtz ten Brink M, Manheim FT, 1998. Metal concentrations in surface sediments of Boston Harbor - changes with time. Journal of Marine Environmental Research, 45: 127-155. http://dx.doi.org/10.1016/S0141-1136(97)00027-5.

[9] Buccolieri A, Buccolieri G, Cardellicchio N, Atti AD, Leo AD, Maci A, 2006. Heavy metals in marine sediments of Taranto Gulf (Ionian Sea, Southern Italy). Journal of Marine Chemistry, 99: 227-235. http://dx.doi.org/10.1016/j.marchem.2005.09.009.

[10] Callender E, 2005. Heavy metals in the environment - historical trends. In: Lokkar, B.S., (Ed.), Environmental Geochemistry. In: Holland, H.D., Turekian, K.K., (Eds.), and Journal of Treatise on Geochemistry. Elsevier, Pergamon Oxford, 67-106 pp.

[11] Çevik F, Göksu MZL, Derici OB, Fındık Ö, 2009. An assessment of metal pollution in surface sediments of Seyhan dam by using enrichment factor, geoaccumulation index and statistical analyses. Environmental Monitoring and Assessment, 152: 309-317. http://dx.doi.org/10.1007/s10661-008-0317-3.

[12] Chen WQ, 2007. Heavy metal contamination in western Xiamen Bay sediments and its vicinity, China. Marine Pollution Bulletin, 54: 974 982. http://dx.doi.org/10.1016/j.marpolbul.2007.02.010.

[13] DarvishBastami,K, Bagheri H, aghparast,S Soltani,F, Hamzehpoor,A, Darvish Bastami,M 2012.Geochemical and geo-statistical assessment of selected heavy metals in the surfacesediments of the Gorgan Bay, Iran,; Marine Pollution Bulletin, 64: 2877-2884

[14] De Mora S D, Sheikholeslami M R, 2002. ASTP:Contaminant screening program: Final report: Interpretation of Caspian Sea sediment data. Caspian Environment Program (CEP), 27 pp.

[15] De Mora SJ, Sheikholeslami MR, Wyse E, Azemard S, Cassi R, 2004. An Assessment of Metal Contamination in Coastal Sediments of the Caspian Sea. Marine Pollution Bulletin, 48: 61-77. http://dx.doi.org/10.1016/S0025-326X(03)00285-6. 
[16] Diagomanolin V, Farhang M, Ghazi-Khansari M, Jafarzadeh N, 2004. Heavy metals ( $\mathrm{Ni}, \mathrm{Cr}$, Cu) in the Karoon waterway river. Iran Toxicology Letters, 151:63-68. http://dx.doi.org/10.1016/j.toxlet.2004.02.018.

[17] ElNemr AH, El Sikaily A, Khaled A, 2007. Total and leachable heavy metals in muddy and sandy sediments of Egyptian coast along Mediterranean Sea, Estuar. Journal of Coastal and Shelf Science, 129:151-168.

[18] Feng H, Han X, Zhang W, Yu L, 2004. A preliminary study of heavy metal contamination in Yangtze River intertidal zone due to urbanization. Marine Pollution Bulletin, 49: 910-915. http://dx.doi.org/10.1016/j.marpolbul.2004.06.014.

[19] Filibeli A, Yilmaz R, Alyanak I, 1995. Dredged material of Izmir Harbor: its behavior and pollution potential. Water Science Technology, 32:105-113. Fo"rstner U, Wittmann GTW, 1979. Metal Pollution in the Aquatic Environment. . Journal of Springer-Verlag, Berlin Heidelberg, 486 pp.

[20] Grinwood MJ and Dixon E., 1997. Assessment of risks posed by list II metals to sensitive marine areas (SMAs) and adequacy of existing environmental quality standards (EQSs) for SMA protection. WRc report for English Nature, Contract No.10435-0.

[21] Hamer K, Karius V, 2002. Brick production with dredged harbour sediments: An industrial-scale experiment. Journal of Waste Management, 22: 521-530. http://dx.doi.org/10.1016/S0956-053X(01)00048-4.

[22] Hakanson L, 1980. An ecological risk index for aquatic pollution control. A sedimentological approach. Journal of Water Research, 14: $975-$ 1001. http://dx.doi.org/10.1016/0043-1354(80)90143-8.

[23] Han Y, Du P, Cao J, Eric SP, 2006. Multivariate analysis of heavy metal contamination in urban dusts of Xi'an. Cent. China. Science Total Environment, 355:176-186. http://dx.doi.org/10.1016/j.scitotenv.2005.02.026.

[24] Horowitz AJ, Elrick KA, 1987. The relation of stream sediment surface area, grainsize and composition to trace element chemistry. Applied Geochemistry, 2: 437-451.Huang KM, Lin S, 2003. Consequences and implication of heavy metal spatial variations in sediments of the Keelung River drainage basin, Taiwan. Chemosphere, 53: 1113-1121.

[25] Huang X, Li X, Yue W, Huang L, Li Y, 2003. Accumulation of heavy metals in the sediments of Shenzhen Bay, South China. Journal of Environmental Science, 24: 144-149 (in Chinese with English abstract).

[26] Huang KM, Lin S, 2003. Consequences and implication of heavy metal spatial variations in sediments of the Keelung River drainage basin, Taiwan. Chemosphere, 53: 1113-1121. http://dx.doi.org/10.1016/S0045-6535(03)00592-7.

[27] Hug S. J., Leupin O. X. and Berg M. (2008) Bangladesh and Vietnam: Different groundwater compositions require different approaches to arsenic mitigation.Environ. Sci. Technol. 42: 6318-6323. http://dx.doi.org/10.1021/es7028284.

[28] Irabien M J, Velasco F, 1999. Heavy metals in Oka Rive sediments (Urdaibai National Biosphere Reserve, Northern Spain): Lithogenic and anthropogenic effects. Journal of Environmental Geology, 37:54-63. http://dx.doi.org/10.1007/s002540050360.

[29] Islam KL, Hossain MM, 1986. Effect of ship scrapping activities on soil and sea environment in the coastal area of Chittagong, Bangladesh. Marine Pollution Bulletin, 17: 462- 463. http://dx.doi.org/10.1016/0025-326X(86)90836-2.

[30] Karageorgis AP, Sioulas AI, Anagnostou CL, 2002. Use of surface sediments in Pagassitikos Gulf, Greece, to detect anthropogenic influence. Journal of Geo-Marine Letters: 21, 200-211. http://dx.doi.org/10.1007/s00367-001-0086-2.

[31] Lee CL, Fang MD, Hsieh MT, 1998. Characterization and distribution of metals in surficial sediments in southwestern Taiwan. Marine Pollution Bulletin, 36, 464-471. http://dx.doi.org/10.1016/S0025-326X(98)00006-X.

[32] Long E, MacDonald DD, Smith, SL, Calder FD, 1995. Incidence of adverse biological effects within ranges of chemical concentrations in marine and estuarine sediments. Journal of Environmental Management, 19: 81-97. http://dx.doi.org/10.1007/BF02472006.

[33] Larsen PF, Gaudette H, 1995. Spatial and temporal aspect of sedimentary trace metal concentrations in mid-coast Maine. Marine Pollution Bulletin, 30(7): 437- 44. http://dx.doi.org/10.1016/0025-326X(94)00129-W.

[34] Lewis D.W., Mc Conchie D., 1994, Analytical sedimentology, Chapman \& Hau, 197 p. Liaghati T, Preda M, Cox M, 2004. Heavy metal distribution and controlling factors within coastal plain sediments, Bells Creek catchment, southeast Queensland, Australia. Environment International 29: 935-948.

[35] Lindholm R, 1987. A Practical Approach to Sedimentology. Allen and Unwin, London, 278p. http://dx.doi.org/10.1007/978-94-011-7683-5.

[36] Marchand C, Lallier-Verges E, Baltzer F, Albe'ric AP, Cossa D, Baillif P, 2006. Heavy metals distribution in mangrove sediments along the mobile coastline of French Guiana. Journal of Marine Chemistry, 98: 1-17. http://dx.doi.org/10.1016/j.marchem.2005.06.001.

[37] Maanan M, Zourarah B, Carruesco C, Aajjane A, Naud J, 2004. The distribution of heavy metals in the Sidi Moussa lagoon sediments (Atlantic Moroccan Coast).Journal of African Earth Sciences, 39: 473-483. http://dx.doi.org/10.1016/j.jafrearsci.2004.07.017.

[38] MacDonald DD, Ingersoll CG, Berger TA, 2000. Development and evaluation of consensus-based sediment quality guidelines for freshwater ecosystems. Journal of Arch Environmental Contamination Toxicology, 39: 20-31. http://dx.doi.org/10.1007/s002440010075.

[39] Maher WA, Aislabie J, 1992. Polycyclic aromatic hydrocarbons in near shore marine sediments of Australia. Journal of Science of the Total Environment 112:143-164 http://dx.doi.org/10.1016/0048-9697(92)90184-T.

[40] McCave IN, 1984. Size spectra and aggregation of suspended particles in the deep ocean. Deep-Sea Research, 31: $329-352$. http://dx.doi.org/10.1016/0198-0149(84)90088-8.

[41] McCready S, Birch GF, Long ER, 2006. Metallic and organic contaminants in sediments of Sydney Harbour, Australia and vicinity-a chemical dataset for evaluating sediment quality guidelines. Journal of Environment International, 32: 455- 465. http://dx.doi.org/10.1016/j.envint.2005.10.006.

[42] Morillo, J., Usero, J., Gracia, I., 2004. Heavy metal distribution in marine sediments from the southwest coast of Spain. Chemosphere, 55: 431-442. http://dx.doi.org/10.1016/j.chemosphere.2003.10.047.

[43] Muller G.; Schwermentalle in: Calmano W Forstner U., 1979. Sediment and Toxic substances. 336p.

[44] NOAA, 1999. National Oceanic and Atmospheric Administration. Sediment quality guideline developed for the national status and trends Program. The Center for Coastal Monitoring and Assessment (CCMA) (NOAA Technical Memorandum NOS NCCOS CCMA) 0137P.

[45] Okay OS, Legovic T, T€ufekc V, Egesel L, Morkoc E, 1996. Environmental impact of land-based pollutants on _Izmit Bay (Turkey): shortterm algal bioassays and simulation of toxicity distribution in the marine environment. Archives of Environmental Contamination and Toxicology 31: 459-465. http://dx.doi.org/10.1007/BF00212428.

[46] Reddy MS, Basha S, Kumar VGS, Joshi HV, Ramachandraiah G, 2004. Distribution,enrichment and accumulation of heavy metals in coastal sediments of Alange Sosiya ship scrapping yard, India. Marine Pollution Bulletin, 48: 1055-1059. http://dx.doi.org/10.1016/j.marpolbul.2003.12.011.

[47] Rivail Da Silva M, Lamotte M, Donard OFX, Soriano-Sierra EJ, Robert M, 1996. Metal contamination in surface sediments of mangroves, lagoons and southern Bay in Florianopolis Island. Journal of Environmental Technology, 17, $1035-1046$. http://dx.doi.org/10.1080/09593331708616473.

[48] Selvaraj K, Ram Mohan V, Szefer P, 2004. Evaluation of metal contamination in coastal sediments of the Bay of Bengal, India: geochemical and statistical approaches. Marine Pollution Bulletin, 49: 174-185. http://dx.doi.org/10.1016/j.marpolbul.2004.02.006.

[49] Tam NFY, Wong YS, 2000. Spatial variation of heavy metals in surface sediments of Hong Kong mangrove swamps, Environmental Pollution, 110: 195-205. http://dx.doi.org/10.1016/S0269-7491(99)00310-3.

[50] US EPA-Region II., USACE-New York District., USDOE-BNL., 1999. Fast Track Dredged Material Decontamination Demonstration for the Port of New York and New Jersey. In: Report to Congress on the Water Resources and Development Acts of 1990 (Section 412 ), 1992 (Section 405C), and 1996 (Section 226). EPA 000-0-99000, December 1999.p65. 
[51] Vald'es J, Vargas G, Sifeddine A, Ortlieb L, Guinez M, 2005. Distribution and enrichment evaluation of heavy metals in Mejillones Bay $\left(23^{\circ} \mathrm{S}\right)$, Northern Chile: geochemical and statistical approach. Marine Pollution Bulletin, 50: $1558-1568$. http://dx.doi.org/10.1016/j.marpolbul.2005.06.024.

[52] Woitke P, Wellmitz J, Helm D, Kube P, Lepom P, Litheraty P, 2003.Analysis and assessment of heavy metal pollution in suspended solids and sediments of the river Danube. Chemosphere, 51: 633-642. http://dx.doi.org/10.1016/S0045-6535(03)00217-0.

[53] Wright P, Mason CF, 1999. Spatial and seasonal variation in heavy metals in the sediments and biota of two adjacent estuaries, the Orwell and the Stour, in eastern England. Journal of Science of the Total Environment, 226: 139-156. http://dx.doi.org/10.1016/S0048-9697(98)00383-0.

[54] Zhang L, Ye Xin, Feng H, Jing Y, Ouyang T, Yu X, Liang R, Gao C, Chen W,2007. Heavy metal contamination in western Xiamen Bay sediments and its vicinity, China. Marine Pollution Bulletin, 54: 974-982. http://dx.doi.org/10.1016/j.marpolbul.2007.02.010. 